\title{
Implementasi Program UKM English Club Mahasiswa Non-English Department
}

\author{
Masyitah Noviyanti' ${ }^{1}$, Khurin'in ${ }^{1}$, Evi Mahsunah ${ }^{1}$ \\ ${ }^{1}$ Universitas Nahdlatul Ulama Sidoarjo \\ *Corresponding email: noviyuska@gmail.com
}

Naskah diterima: 24 Januari 2021 | Disetujui: 30 April 2021 | Diterbitkan: 11 Mei 2021

\begin{abstract}
This research aims to find out how was the implementation of The English Club program, especially for non-English department students in Nahdlatul Ulama Sidoarjo University (UNUSIDA), as well as to know about the obstacles during the implementation. This research is a qualitative descriptive research, to collect the data, this research used interviews, observations and documentation. The data analysis technique used is qualitative data analysis, namely data collection, data reduction and conclusion. The results showed that English Club has four main activities, namely English Conversation, English Course, English Fest and Creative Writing. The success of the implementation program can be seen through four aspects such as; kind of programs, material, Tutor quality, and learning environment. The data research showed that $75 \%$ respondents strongly agree that the implementation of English club programs has succeeded. There are some obstacles to the implementation of English club programs such as; Sidoarjo is the red zone of Covid-19 pandemic, so several programs cannot run well. It is difficult to arrange the schedule which should be suitable for all the members from different program study. The last is the busyness of English Club members with other activities outside the English Club.
\end{abstract}

Keywords: implementation, english club, non english department, unit of students activities

\begin{abstract}
Abstrak
Penelitian ini bertujuan untuk mengetahui bagaimana implementasi kegiatan UKM English Club mahasiswa non-English Department Universitas Nahdlatul Ulama Sidoarjo (UNUSIDA), serta mengetahui tentang kendala yang terdapat dalam implementasi tersebut. Jenis penelitian ini adalah deskriptif kualitatif. Penelitian ini mengambil lokasi di Universitas nahdlatul Ulama Sidoarjo. Metode pengumpulan data yang digunakan adalah interview, wawancara, dan observasi. Teknik analisis data yang digunakan adalah analisis data kualitatif, yaitu pengumpulan data, reduksi data dan penarikan kesimpulan. Hasil penelitian menunjukkan bahwa English Club UNUSIDA yang didirikan tahun 2016 ini memiliki empat kegiatan utama yaitu English Conversation, English Course, English Fest dan menulis kreatif. Keberhasilan implementasi program UKM English Club dapat diukur dari empat sisi, yaitu jenis kegiatan, materi, kualitas pemateri, dan lingkungan belajar. Hasil angket menunjukkan bahwa $75 \%$ responden sangat setuju implementasi program berjalan dengan baik. Faktor pendorong interaksi sosial dalam kelompok English Club antara lain tergantung pada instruksi dan materi dari pemateri, lalu adanya kerjasama kelompok dalam berbagai kegiatan dalam English Club. Faktor penghambat dalam English Club adalah adanya wabah Covid-19, sulitnya menentukan jadwal yang bisa menyesuaikan dengan jadwal anggota yang berasal dari Sembilan prodi yang berbeda dan adanya kesibukan dari anggota English Club dengan kegiatan lain diluar English Club.
\end{abstract}

Kata kunci: implementasi, english club, non english department, unit kegiatan mahasiswa

2656-9779 (C) 2020 The Author(s).

Published by Lembaga Penerbitan dan Publikasi Ilmiah Program Pascasarjana IAI Sunan Giri Ponorogo. This is an open access article under the CC BY-SA 4.0 license. DOI: 10.37680/qalamuna.v13i1.588 


\section{Pendahuluan}

Perkembangan zaman menuntut pentingnya penguasaan bahasa Inggris bagi masyarakat terdidik di Indonesia. Kebutuhan akan bahasa Inggris berkaitan dengan kemampuan berkomunikasi secara lisan maupun tulis dan menjadi prioritas bagi peningkatan sumber daya manusia bagi pembangunan bangsa. Hal ini dikarenakan bahasa Inggris merupakan bahasa yang paling banyak digunakan di dunia, lebih dari 400 juta orang di seluruh dunia menggunakan bahasa Inggris baik di tempat kerja maupun di kehidupan sosial (Iriance, 2018).

Bahasa Inggris menjadi komponen materi wajib pendidikan di Indonesia, hal tersebut dapat diperoleh secara formal pada pendidikan sekolah dasar hingga perguruan tinggi. Bahasa Inggris juga merupakan bahasa asing yang memiliki peranan penting yang wajib dikuasai oleh semua civitas akademika, terutama mahasiswa agar mampu dalam berkomunikasi, menulis, membaca dan memahami literatur bahasa Inggris. Oleh karena itu, Indonesia juga harus menempatkan bahasa Inggris pada posisi yang sama dengan bahasa Indonesia sehingga dapat berperan lebih besar pada tataran internasional dalam bidang ilmu pengetahuan, ekonomi, politik, teknologi, dan budaya. Pemerintah Indonesia mengeluarkan pasal 33 ayat 3 UU Nomor 20 Tahun 2003 yang berbunyi "Bahasa asing dapat digunakan sebagai bahasa pengantar pada satuan pendidikan tertentu untuk mendukung kemampuan berbahasa asing peserta didik." Itulah salah satu alasan terpenting mengapa manusia harus mempelajari bahasa Inggris di sekolah (Undang-Undang Republik Indonesia Nomor 20 Tahun 2003 Tentang Sistem Pendidikan Nasional Dengan, 2006).

Di Universitas Nahdlatul Ulama Sidoarjo (UNUSIDA) pengajaran bahasa Inggris diberikan bukan hanya kepada mahasiswa jurusan bahasa Inggris saja, namun juga kepada mahasiswa jurusan lain (non-English Department). Mata Kuliah bahasa Inggris menjadi Mata Kuliah Umum (MKU) yang wajib ditempuh pada awal semester selama satu hingga dua semester sesuai dengan kebijakan program studi. Silabus dan bahan ajar dirancang sesuai dengan kebutuhan program studi yang ada. Akan tetapi berdasarkan hasil evaluasi pelaksanaan pengajaran bahasa Inggris di Universitas Nahdlatul Ulama menunjukkan masih rendahnya kemampuan yang dimiliki mahasiswa non jurusan bahasa Inggris (non-English Department), hal itu dibuktikan dengan skor rata-rata mahasiswa yang mendapat nilai $\mathrm{C}$ sebanyak $60 \%$.

Berbagai faktor diduga menjadi penyebab rendahnya kemampuan bahasa Inggris mahasiswa, salah satunya adalah lingkungan belajar yang kurang mendukung dan kurangnya pembinaandalam mempelajari bahasa Inggris. Bahasa Inggris bukan hanya tentang teori dan aturan tata bahasa saja, namun juga membutuhkan praktek, sebagaimana yang disampaikan oleh Finocchiaro dan Brumfit (Werdiningsih, 2001) yang menyatakan bahwa dalam proses belajar mengajar pada pembelajaran bahasa sebaiknya menitikberatkan pada penggunaan bahasa bukan pada pengetahuan tentang bahasa. Artinya, bahwa pembelajaran bahasa selayaknya memaksimalkan penggunaannya secara praktis dan komunikatif. Permasalahan kedua yaitu rendahnya kualitas bahasa Inggris mahasiswa khususnya mahasiswa non bahasa Inggris, penyebabnya adalah masih kurangnya kesadaran siswa dalam mempelajarinya. Oleh karena itu, sudah seharusnya mahasiswa mengikuti berbagai kegiatan tambahan seperti les prifat atau kelompok belajar lainnya.

English Club merupakan sebuah kelompok belajar Bahasa Inggris yang bertemu secara rutin untuk belajar dan praktek berbahasa Inggris. Tidak hanya itu, pembelajarannya juga berusaha memecahkan permasalahan belajar anggotanya (Malu and Smedley, 2016). English Club merupakan 
salah satu UKM di Universitas Nahdlatul Ulama Sidoarjo (UNUSIDA). Pada UKM ini mahasiswa diberi kesempatan untuk ikut serta mengembangkan keterampilan bahasa Inggrisnya dengan mengikuti program-program yang disediakan. Program tersebut meliputi keterampilan membaca (reading), menulis (writing), mendengar (listening), dan berbicara (speaking). Sejak didirikan pada tanggal 20 November 2016 English Club UNUSIDA tercatat memiliki 70 anggota yang berasal dari 9 program studi di luar program studi pendidikan bahasa Inggris. Dengan bergabung dalam UKM ini, mahasiswa non english department diharapkan mampu menambah kemampuan berbahasa inggrisnya menjadi lebih baik. Hal ini selaras dengan ungkapan Fitria yang dalam penelitiannya menyebutkan bahwa salah satu cara meningkatkan kesadaran mahasiswa untuk belajar bahasa Inggris adalah dengan mengikuti kegiatan Unit Kegiatan Mahasiswa (UKM) bahasa Inggris seperti English Club, kegiatan ini dapat menjadi wadah untuk setiap mahasiswa agar mampu berkomunikasi dengan baik menggunakan bahasa Inggris dan menambah wawasan serta kompetensi mahasiswa dalam berbahasa Inggris (Fitria, 2018). Oleh karena itulah penelitian ini dilaksanakan untuk mengetahui bagaimana implementasi program English Club non English department UNUSIDA.

Penelitian ini menggunakan pendekatan deskriptif kualitatif. Penelitian deskriptif merupakan penelitian yang mengungkapkan masalah, keadaan atau peristiwa sebagaimana yang nyata terjadi dalam arti temuan fakta (Fact-Finding). Adapun tujuan dari penelitian ini adalah untuk mengungkapkan kejadian atau fakta, keadaan, fenomena (Sugiyono, 2010), variabel dan keadaan yang terjadi dalam implementasi kegiatan program English Club mahasiswa non-English Department UNUSIDA.

Metode pengumpulan data yang digunakan adalah wawancara, observasi, dan dokumentasi. Sedangkan teknik analisis data yang digunakan adalah kualitatif yang dilakukan melalui beberapa tahap, yaitu pengumpulan data, reduksi data, dan penarikan kesimpulan. Data yang dikumpulkan dari informan menghasilkan paparan tentang UKM English Club UNUSIDA, terjadinya interaksi sosial antar anggota, baik dari mahasiswa non English Department maupun dari English Department dan faktor pendorong serta faktor penghambat dalam interaksi sosial pada UKM English Club UNUSIDA. Tahap selanjutnya adalah seleksi data, dalam hal ini dilakukan penyederhanaan keterangan yang sudah didapatkan di lapangan, kemudian dikelompokkan secara terpisah antara data mengenai profil UKM English Club UNUSIDA, terjadinya interaksi sosial dalam UKM English $C l u b$, serta faktor pendorong dan faktor penghambat dalam interaksi sosial pada UKM English Club UNUSIDA. Setelah itu, data disajikan secara rapi dan tersusun sistematis sehingga dapat ditarik kesimpulan.

\section{Keterampilan Bahasa Inggris Mahasiswa}

Bahasa Inggris di Indonesia telah semakin intensif dan ekstensif dipelajari. Kemahiran bahasa Inggris (English proficiency) dijadikan sebagai syarat penerimaan dan penamatan mahasiswa program S1, S2, dan S3 di beberapa perguruan tinggi. Selain itu, bahasa Inggris juga digunakan sebagai syarat melamar kerja dibeberapa perusahaan. Pada tingkat perguruan tinggi, bahasa Inggris merupakan bahasa asing yang mempunyai peranan penting dan harus dikuasai oleh seluruh civitas akademika, khususnya mahasiswa. Biasanya, mahasiswa diwajibkan dalam setiap kegiatan akademik terutama ketika berkomunikasi, presentasi, mengikuti kompetisi-kompetisi dan membaca literatur yang ditulis dalam bahasa Inggris. 
Keterampilan dalam berbahasa Inggris dikategorikan menjadi empat (Syahril dan Munir, 2014). Keterampilan yang pertama adalah Speaking Skill. Dalam Speaking skill teknik berbicara yang dipelajari berupa pengucapan kata-kata yang dapat membentuk kemampuan active English atau kemampuan berbicara bahasa Inggris dengan komunikasi aktif. Keterampilan yang kedua adalah Reading Skill. Dalam reading skill, dipelajari tentang bagaimana membaca kata-kata dalam bahasa Inggris serta memperbanyak kosa kata bahasa Inggris (Vocabulary). Terdapat teknik dalam reading skill yaitu membaca cepat atau scanning, artinya bahan bacaan bahasa Inggris dibaca secara menyeluruh dalam waktu yang singkat dan poin inti dari setiap bacaan tersebut dijadikan fokus bacaan. Melalui skill tersebut dapat diketahui main idea (ide pokok), topik dari sebuah bacaan berbahasa Inggris, dan kalimat pendukung tulisan tersebut. Keterampilan yang ketiga adalah Listening Skill. Listening Skill merupakan keterampilan mendengar, memahami, dan merespon percakapan berbahasa Inggris. Pada umumnya jika penutur berasal dari negara Asia Tenggara, bahasa Inggris yang digunakan lebih mudah untuk didengarkan dan dipahami oleh pendengar dari penutur bahasa yang sama. Hal tersebut terjadi karena logat atau cara bicara yang sama seperti bahasa keseharian penutur dalam pengucapannya. Untuk belajar bahasa Inggris dalam bidang listening skill disarankan memperbanyak mendengarkan lagu atau menonton film berbahasa Inggris lalu menyimak kata demi kata sehingga dapat diketahui bagaimana cara pengucapan kata yang benar.

Keterampilan yang keempat adalah Writing Skill. Dalam writing skill atau keterampilan menulis merupakan kemampuan yang lumayan rumit karena dalam menulis bahasa Inggris harus mengetahui grammar dan susunan kata. Jika salah menuliskan grammar, maka makna yang terkandung akan berbeda. Dalam writing skill ada istilah tenses, yaitu susunan kata yang sesuai dengan waktu kejadiannya seperti present tense, present continuous tense, past tense, past continuous tense, present past tense, modal dan lain sebagainya. Banyak yang harus dipahami dalam menulis writing skill agar pemilihan diksinya dapat tersusun dengan baik dan benar. Dari keempat jenis kemampuan bahasa Inggris tersebut, mahasiswa diharuskan untuk menguasainya dengan baik. Penguasaan kemampuan bahasa Inggris tersebut tidak hanya untuk mahasiswa dari jurusan bahasa Inggris saja melainkan juga untuk mahasiswa yang non bahasa Inggris (non-English Department).

\section{Mahasiswa Non-English Department}

Pengajaran bahasa Inggris di Universitas Nahdlatul Ulama Sidoarjo (UNUSIDA) tidak hanya dilakukan pada mahasiswa program studi pendidikan bahasa Inggris (PBI), melainkan pada seluruh mahasiswa yang ada di UNUSIDA. Hal ini juga terjadi karena bahasa Inggris merupakan mata kuliah wajib dasar yang termasuk dari mata kuliah pengembangan diri (Unsri, 2011). Oleh karena itu, seluruh mahasiswa non-English department di UNUSIDA harus menempuh mata kuliah bahasa Inggris Dasar selama satu semester.

Terdapat sembilan prodi non-English department di UNUSIDA yang mewajibkan para mahasiswa untuk mengikuti mata kuliah bahasa Inggris dasar. Mahasiswa tersebut berasal dari Prodi Pendidikan Guru Sekolah Dasar, Manajemen, Akuntansi, Teknik Lingkungan, Teknik Kimia, Teknik Industri, Sistem Informasi, Desain Komunikasi Visual (DKV) dan Teknik Informatika. Subjek penelitian ini adalah seluruh mahasiswa non-English department dan dibatasi hanya mahasiswa yang mengikuti program UKM English Club yang dikelola oleh Himpunan Mahasiswa Program Studi (HIMAPRODI) Pendidikan Bahasa Inggris di UNUSIDA. 


\section{Program English Club UNUSIDA}

Program English Club UNUSIDA merupakan Unit Kegiatan Mahasiswa (UKM) yang dikelola Himpunan Mahasiswa yang bertujuan untuk mengembangkan keterampilan bahasa Inggris mahasiswa UNUSIDA baik dari prodi PBI maupun dari luar prodi PBI (non-English department). Program English Club didirikan pada tanggal 20 November 2016 dengan susunan kepengurusan yang terdiri dari mahasiswa PBI. Program ini telah diikuti oleh 70 mahasiswa UNUSIDA dari berbagai prodi. Jumlah mahasiswa Non-English Department yang mengikuti program English Club adalah 40 mahasiswa yang berasal dari beberapa prodi, diantaranya Prodi Manajemen, Akuntansi, DKV, Teknik Industri, Teknik Lingkungan, Teknik Informatika, dan Prodi Sistem Informasi. Seluruh anggota English Club terdiri dari angkatan tahun 2016, 2017, 2018 dan 2019.

Program English Club UNUSIDA dilaksanakan dua kali dalam satu minggu, yaitu pada hari Selasa dan Jumat. Setiap pertemuan yang dilaksanakan membahas keterampilan-keterampilan dalam bahasa Inggris, diantaranya listening (mendengarkan), speaking (berbicara), reading (membaca) dan writing (menulis). Setiap program kegiatan dipandu oleh beberapa tutor dari mahasiswa Pendidikan Bahasa Inggris (PBI). Melalui pelaksanaan program ini diharapkan dapat meningkatkan keterampilan bahasa Inggris seluruh mahasiswa UNUSIDA khususnya mahasiswa Non-English Department.

\section{Implementasi Program UKM English Club UNUSIDA}

UKM English Club didirikan pada tanggal 20 November 2016 dengan jumlah peserta kurang dari 50. Namun sejalan dengan berkembangnya UKM-UKM di lingkungan UNUSIDA, maka peserta English Club juga semakin bertambah. Berdasarkan hasil wawancara peneliti dengan pengurus UKM English Club diketahui bahwa pada tahun 2020 peserta UKM English Club UNUSIDA tercatat memiliki 70 anggota yang berasal dari 9 program studi yang berbeda-beda. Sedangkan pengurus UKM berjumlah 10 orang yang berasal dari anggota senior angkatan 2017 dan 2018. 70 anggota dan 5 dari pengurus inilah yang menjadi responden penelitian ini. Pembina UKM English Club ini adalah salah satu dosen dari Prodi Pendidikan Bahasa Inggris UNUSIDA.

Kegiatan yang dilakukan pada UKM ini diantaranya melatih anggota untuk mengasah keterampilan Bahasa Inggris melalui program English Conversation seperti public speaking, debating, program kreatif menulis, english course, dan english fest. Secara khusus tujuan dari English Club sama dengan kegiatan dalam Intensive English Course yang ada di kampus-kampus lain yang bertujuan untuk meningkatkan kemampuan memahami wacana lisan bahasa Inggris yang wajar, meningkatkan kemampuan memahami wacana bahasa Inggris tulis yang sederhana dalam bentuk narasi dan deskripsi, meningkatkan keterampilan mengucapkan bunyi dan tata bahasa Inggris, memahami dan menggunakan ungkapan dan kalimat sederhana dengan intonation, stress pattern, dan rhythm yang benar, meningkatkan keterampilan membuat karangan sederhana dalam bahasa Inggris, serta meningkatkan keterampilan memahami dan menggunakan kosakata pada pola kalimat bahasa Inggris sesuai dengan tingkat penguasaan mahasiswa dan kebutuhan komunikatif yang nyata (Masduki, 2018).

Program English Club sebenarnya sudah berjalan dengan baik, namun sejak bulan April 2020 program tersebut berjalan tidak maksimal karena adanya wabah COVID 19 yang menyebar di seluruh penjuru dunia, termasuk kota Sidoarjo yang menjadi Zona merah Covid, sehingga pemerintah 
setempat melarang semua aktivitas yang melibatkan kerumunan, termasuk dibidang pendidikan harus berjalan secara daring. Dalam implementasinya kegiatan English Club dianalisis dari empat bagian pokok, yaitu program kegiatannya, materi kegiatan, kualitas pemateri dan terakhir dari segi lingkungan belajar.

\section{Program Kegiatan UKM English Club}

UKM English Club UNUSIDA memiliki berbagai macam program kegiatan yang dapat diikuti oleh semua anggotanya. Program yang pertama adalah Public Speaking, program ini diikuti oleh semua anggota. Pada kegiatan ini anggota dipandu oleh tiga orang pembina yang berasal dari pengurus untuk berdiskusi dan praktek conversation melalui permainan dan juga bermain peran. Kegiatan dikemas dengan suasana santai dan biasanya dilaksanakan di kelas, halaman universitas atau laboratorium Bahasa, di mana mahasiswa duduk dengan cara melingkar dan Pembina English Club memulai dengan membuat pembicaraan kecil (small talk) mengenai suatu topik, seperti story telling, news reading, debate dan lain-lain. Setelah itu pembina English Club memberi instruksi atau perintah kepada anggotanya tentang apa saja yang akan mereka lakukan.

Materi yang didiskusikan setiap pertemuan English Club berbeda beda, misalnya pada awal minggu mahasiswa belajar tentang Spelling, Pronunciation, Speaking dengan berbagai macam topik sederhana. Contoh materi English Speaking seperti topik tentang How to introduce yourself and Others, favorite food/artist dan topik lainnya yang dapat menstimulasi atau merangsang anggotanya untuk dapat berpartisipasi dalam kegiatan speaking, kemudian di minggu berikutnya akan diberikan topik atau bahasan yang berbeda.

Dalam rangka menambah pengalaman dan pengetahuan peserta, pada tanggal 12 Agustus 2020, English Club mengadakan seminar yang dikemas dalam kegiatan public speaking dengan mendatangkan narasumber seorang penyiar dari Radio Suara Andika Kediri.

Program kegiatan kedua dari English Club UNUSIDA adalah English course, kegiatan ini diikuti oleh $76 \%$ dari total anggota. Program ini menawarkan bimbingan atau kursus Bahasa Inggris secara intensif dengan materi-materi yang disesuaikan dengan kebutuhan anggota. Materi tidak sebatas Speaking atau Reading saja, namun juga meliputi Grammar dan Vocabulary, materi terkadang juga membahas kesulitan-kesulitan anggota saat mengerjakan tugas mata kuliah Bahasa Inggris. Kegiatan ini dilakukan setiap hari Jum'at, pukul satu siang sampai pukul tiga sore.

English Fest merupakan bentuk kegiatan lain yang ada di English Club, program ini merupakan program favorit yang menjadi andalan dan menjadi ciri khas dari UKM. Kegiatan ini berbentuk festival di mana para anggota berkesempatan menampilkan kemampuannya dalam berbahasa Inggris melalui unjuk perform di atas panggung yang biasanya berbentuk drama, lagu, atau juga berpidato. Kegiatan ini dilaksanakan berpindah-pindah dan dilakukan di panggung ruang terbuka dengan harapan mereka dapat lebih semangat dan tidak bosan dengan suasana pembelajaran di kelas. Hal ini juga dilakukan untuk mengenalkan anggota terutama mereka yang berasal dari daerah luar Sidoarjo agar lebih mengetahui tempat-tempat menarik yang ada di Sidoarjo. Kegiatan ini diadakan setiap enam bulan sekali, namun para anggota biasanya mempersiapkan acara ini selama kurang lebih dua bulan agar dapat tampil dengan baik saat English Fest. 


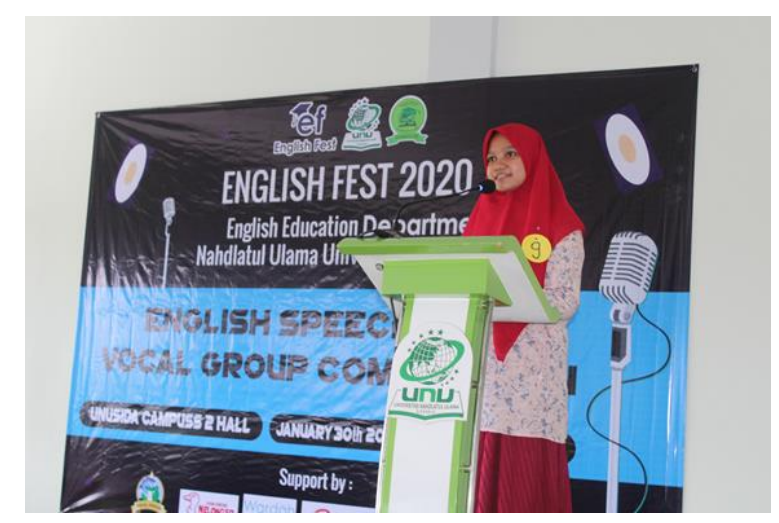

Gambar 1. Speech Contest English Fest

Program lainnya adalah debate dan menulis kreatif yang berupa English Corner dan English Magazine. English Corner berbentuk majalah dinding yang ada di beberapa lorong dan teras kampus UNUSIDA. Sedangkan English Magazine merupakan majalah yang terbit tiga bulan sekali yang berisi tulisan-tulisan kreatif anggota dan wawancara dengan dosen atau mahasiswa berprestasi UNUSIDA.

Berdasarkan hasil wawancara diketahui bahwa peserta yang berminat mengikuti program ini hanya sebesar $40 \%$ dari anggota. Hal ini disebabkan masih banyak anggota terutama mereka yang berasal dari non English department merasa tidak percaya diri dengan tulisan mereka untuk ditampilkan di English Corner ataupun di English Magazine. Namun, pengurus English Club percaya bahwa kedepannya program ini akan dikelola lebih baik sehingga peminatnya juga akan bertambah.

Hasil angket penelitian ini menunjukkan bahwa banyak anggota yang mengikuti lebih dari satu program di English Club. Sebagai contoh sebagian besar anggota ikut program English Speaking, English course dan English fest. Responden juga memaparkan bahwa jadwal kegiatan yang ada di English Club tidak mengganggu jadwal perkuliahan. Hal ini dikarenakan pengurus sudah mengadakan diskusi dengan semua anggota terutama mereka yang berasal dari prodi non English Department mengenai waktu dan tempat kegiatan English Club agar semua program terlaksana dengan baik. Ada $71 \%$ responden menyatakan sangat setuju bahwa program-program yang ada di English Club berjalan dengan baik.

\section{Materi Kegiatan English Club}

Salah satu hal yang terpenting dalam implementasi program kegiatan di English Club adalah kualitas materi kegiatan. Materi ini juga harus disesuaikan dengan kebutuhan dan latar belakang anggota yang berasal dari non English Department. Sebagian besar dari mereka ingin meningkatkan kemampuan berbicaranya dalam berbahasa Inggris agar mudah mengikuti perkuliahan MKU Bahasa Inggris. Berdasarkan angket penelitian yang diberikan ke responden dapat diketahui bahwa materi yang disediakan mudah dipelajari dan variatif. Ada 62 peserta yang sangat setuju dengan pernyataan tersebut. Namun materi atau kegiatan di English Club masih perlu diperbaiki lebih lanjut agar dapat sesuai dengan kebutuhan para anggotanya. Hasil angket menunjukkan ada 10 responden yang menyatakan bahwa materi yang ada selama ini tidak memenuhi kebutuhan mereka, yang artinya materi masih kurang sesuai dengan harapan anggota. Selain itu referensi materi yang up to date mengikuti trend yang ada saat ini juga menjadi perhatian saat merumuskan materi di English Club. 


\section{Kualitas Pemateri}

Pemateri utama yang memberikan tutorial di English club berasal dari perwakilan pengurus dan mahasiswa senior yang berasal dari Prodi Pendidikan Bahasa Inggris. Selain itu, pengurus juga mengundang dosen-dosen dari dalam kampus UNUSIDA terutama dosen dari Fakultas FKIP untuk mengisi materi di UKM. Setiap satu semester sekali pengurus English Club juga mengundang pemateri dari luar yang dapat berasal dari ahli pendidikan, penyiar radio, maupun ahli-ahli lain yang berkompeten dan mempunyai prestasi khusus serta dapat menginspirasi anggota English Club. Pengurus English Club dalam rapat bulanannya juga membahas pemateri dan evaluasinya dari anggota. Dengan demikian pemateri dapat merefleksi diri dan menemukan potensi serta kelemahan dari kegiatan pembelajaran atau tutorial yang disampaikan. Kualitas pemateri di English Club berdasarkan hasil angket menunjukkan ada $81 \%$ responden sangat setuju bahwa pemateri pintar dan Bahasa Inggrisnya baik dalam menyampaikan materi dan menggunakan media pembelajaran.

\section{Lingkungan Belajar}

Pemilihan tempat belajar dapat membantu seseorang untuk lebih bersemangat dalam belajar serta mempermudah dalam menerima pembelajaran. Oleh karena itu, dalam mengimplementasi program kegiatan di English Club, para pengurus memutuskan untuk menemukan lingkungan belajar yang kondusif dan tertib. Untuk pertemuan rutin yang diadakan pada hari Rabu dan Jumat diadakan di balkon lantai 2 Gedung Rohmatul Ummah UNUSIDA atau di sekitar lingkungan kampus UNUSIDA. Bahkan dua atau tiga bulan sekali mereka mengadakan kegiatan di luar lingkungan kampus seperti di alun-alun kota, tempat perkemahan ataupun di taman. Sebagai contoh kegiatan English Fest bulan Maret 2020 diadakan di lapangan Koramil Kecamatan Jabon-Sidoarjo.

Hasil survei angket menunjukkan ada 63\% responden sangat setuju dengan pemilihan lingkungan outdoor karena implementasi program kegiatan English Club yang menarik sehingga interaksi sosial antar anggota dari berbagai program studi terjalin dengan baik. Namun ada 23 responden yang menyatakan tidak setuju tentang pemilihan lingkungan belajar English Club, karena terlalu berisik dan mengurangi konsentrasi. Selain itu, sejak diberlakukannya social distancing kegiatan English Club tidak dapat dilaksanakan di luar kampus atau di tempat terbuka lainnya.

Secara keseluruhan, implementasi program UKM English Club UNUSIDA berdasarkan hasil angket yang diperoleh dari responden dapat diketahui bahwa ada $75 \%$ responden menyatakan sangat setuju bahwa implementasi program kegiatan English club UNUSIDA berjalan dengan baik, pemilihan materi juga sesuai dengan harapan responden. Kualitas pemateri dan pemilihan lingkungan belajar juga sudah baik. Untuk lebih detailnya dapat dilihat pada gambar 1. 


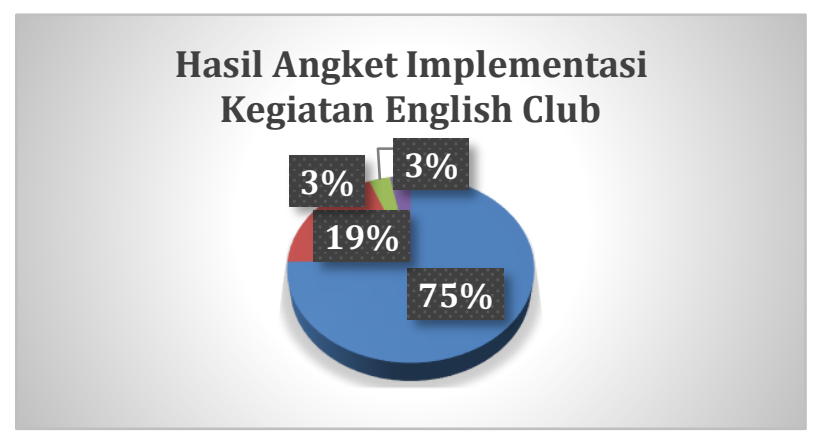

Gambar 2. Hasil Angket Penelitian

\section{Keterangan:}

75\% sangat setuju implementasi program berjalan dengan baik.

$19 \%$ setuju implementasi program berjalan dengan baik.

$3 \%$ kurang setuju implementasi program berjalan dengan baik.

3\% tidak setuju implementasi program berjalan dengan baik.

\section{Kendala-Kendala Implementasi Program UKM English Club}

Program-program English Club sebenarnya sudah berjalan dengan baik, namun sejak bulan April 2020 program tersebut berjalan tidak maksimal. Hal ini dikarenakan adanya wabah Covid-19 yang menyebar di seluruh penjuru dunia, termasuk kota Sidoarjo yang berstatus zona merah sehingga pemerintah setempat melarang semua aktivitas yang melibatkan kerumunan. Sejak diberlakukannya social distancing, kegiatan English Club sering tidak bisa diimplementasikan di luar kampus atau di tempat terbuka lainnya. Pandemi Covid-19 merupakan musibah yang memilukan seluruh penduduk bumi. Banyak negara memutuskan menutup sekolah, perguruan tinggi maupun universitas, termasuk Indonesia (Aji, 2020). Oleh karena itu, pengurus dan anggota memutuskan untuk melakukan kegiatan secara daring.

Selain karena pandemic, kendala lain dari implementasi program UKM adalah sulitnya menyesuaikan jadwal UKM dengan jadwal kuliah pada sembilan prodi yang berbeda. Akibatnya, ada beberapa mahasiswa non English department yang tidak dapat mengikuti program kegiatan yang ditawarkan. Untuk mengatasi permasalahan tersebut, pengurus English Club berkonsultasi dengan pihak-pihak terkait seperti Kaprodi atau wakil kemahasiswaan untuk berkonsultasi mengenai jadwal perkuliahan di prodi tersebut. Hal ini dilakukan agar segera mendapatkan informasi yang akurat sehingga dapat menyusun jadwal program kegiatan dengan baik sehingga banyak mahasiswa yang bergabung dalam kegiatan ini.

\section{Kesimpulan}

Implementasi Program UKM English Club di Universitas Nahdlatul Ulama Sidoarjo memiliki empat kegiatan utama yaitu English Conversation, English Course, English Fest dan menulis Kreatif. Keberhasilan implementasi program UKM English Club dapat diukur dari empat sisi, yaitu jenis kegiatan, materi, kualitas pemateri, dan lingkungan belajar. Berdasarkan hasil penelitian 
menunjukkan bahwa $75 \%$ responden sangat setuju implementasi program berjalan dengan baik. Faktor pendorong interaksi sosial dalam kelompok English Club antara lain tergantung pada instruksi dan materi dari pemateri serta adanya kerjasama kelompok dalam berbagai kegiatan dalam English Club.

Terdapat tiga faktor utama penghambat implementasi program English Club. Diantaranya, wabah Covid-19 yang mengakibatkan beberapa kegiatan tidak dapat terlaksana. Sulitnya menyesuaikan jadwal kegiatan dengan jadwal anggota yang berasal dari sembilan prodi berbeda. Selain itu, adanya kesibukan dari anggota English Club dengan kegiatan lain diluar English Club juga menjadi faktor penghambat implementasi program English Club.

\section{Pernyataan/Acknowledgement}

Ucapan terimakasih kami sampaikan kepada:

1. RISTEKDIKTI yang telah mendanai pelaksanaan penelitian ini.

2. UNIVERSITAS NU SIDOARJO yang telah mengijinkan pelaksaan penelitian ini.

\section{Referensi}

Aji, R. H. (2020) 'Dampak Covid-19 pada Pendidikan di Indonesia: Sekolah, Keterampilan, dan Proses Pembelajaran', SALAM; Jurnal Sosial \& Budaya Syari FSH UIN Syarif Hidayatullah Jakarta Vol. 7, 7(5), pp. 395-402.

Available at: http://www.akrabjuara.com/index.php/akrabjuara/article/view/919.

Fitria, T. N. (2018) 'Implementasi Program Kegiatan English Club Sebagai Salah Satu KEGIATAN MAHASISWA DI STIE AAS SURAKARTA', (September).

Iriance (2018) 'Bahasa Inggris Sebagai Bahasa Lingua Franca dan Posisi Kemampuan Bahasa Inggris Masyarakat Indonesia Diantara Anggota MEA', Prosiding Industrial Research Workshop and National Seminar.

Malu, K. F. and Smedley, B. (2016) 'Community-Based English Clubs : English Practice and Social Change Outside the Classroom', English Teaching Forum. Available at: https://files.eric.ed.gov/fulltext/EJ1114170.pdf.

Masduki (2018) 'Studi Kemampuan Berbahasa Inggris Mahasiswa Non-English Department Melalui Kegiatan Intensive Course Model B', Trunojoyo, 4(1), pp. 39-45.

Sahril dan Munir, N. (2014) 'Peningkatan Kemampuan Bahasa Inggris Mahasiswa Semester II STAIN Datokarama Palu melalui Pair-Dictation .', Jurnal Penelitian Ilmiah ISTIQRA. Vol. 2, No. 1, Januari-Juni.IAIN Palu., 2(1), p. 2014.

Sugiyono, P. D. (2010) 'Metode Penelitian Bisnis. Pendekatan Kuantitatif, kualitatif dan R\&D', Bandung: Alfabeta.

Undang-Undang Republik Indonesia Nomor 20 Tahun 2003 Tentang Sistem Pendidikan Nasional Dengan (2006).

Available at: https://sipuu.setkab.go.id/PUUDOC/7308/UU0202003.HTM\%0A\%0A. 
Unsri (2011) Buku Pedoman Akademik dan Kemahasiswaan Universitas Sriwijaya. Palembang. Palembang: Penerbit Unsri Palembang.

Werdiningsih, D. (2001) 'Pengembangan Program Pembelajaran BI Ragam IPTEK di UNISMA .', Laporan Penelitian. Malang : FKIP UNISMA Malang, p. 2001. 
Implementasi Program UKM English Club Mahasiswa Non-English Departement Masyitah Noviyanti, Khurin'in, Evi Mahsunah 